\title{
New Mode of Football Teaching in Colleges and Universities Under the Background of the Internet
}

\author{
Wei Xu \\ College of Technology and Art \\ Jingdezhen Ceramic Institute \\ Jingdezhen, Jiangxi, China, 333001
}

\begin{abstract}
With the advent of the Internet era, people's lives have undergone great changes. Teaching under the background of the Internet has had a strong impact on traditional teaching content, teaching mode and evaluation standard. In a new teaching context, football teaching in colleges and universities presents a new teaching standard. This work drew on the research results based on the Internet mode at home and abroad, and built a football teaching mode in sport universities based on "virtual situational" network. It aimed to promote the reform of football teaching mode and teaching methods in sport universities and promote the development of teaching mode based on the Internet in colleges and universities.
\end{abstract}

Keywords-Internet; Football Teaching; Colleges and Universities; Teaching Mode

\section{INTRODUCTION}

Most of the current football classroom teaching in sport universities of China is still based on the "transmit and acceptance" teaching mode. To a certain extent, it is still centered on teachers, which means students listen to teachers passively and only accomplish the assignments arranged by teachers. In contrast, the network teaching mode breaks through the space and time constraints of traditional classroom teaching and provide students and teachers with an interactive platform, which can help students exert their subjective initiative. Therefore, students can change passive learning into active learning, which can promote the reform of football teaching mode and teaching methods in sport universities.

\section{Shortcomings of Traditional Football TEACHING MODE}

\section{A. In the aspect of infrastructure investment}

Compared with other types of sports, football has relatively high requirements on venues and infrastructure. If the infrastructure is not perfect, many football teaching activities and competition exercises cannot be carried out well. Football teaching activities require a lot of practical exercises, so that students can be more proficient in playing football. At the present stage, some colleges and universities have limited investment in football infrastructure, some of which have difficulty in ensuring sufficient sports venues. What is worse, the existing venues cannot meet the requirements of football and training since facilities are not perfect. In the process of actual physical education, the sports equipment is not perfect enough to provide reliable infrastructure support for football teaching activities.

\section{B. In the aspect of teaching methods}

The traditional teaching method pays more attention to the teaching of football skills, and mainly relies on demonstration and explanation to teach, which is relatively passive and lacks enough attraction for students, so it is difficult for students to generate enough participation interest, and it is also very unfavorable for the effective development of football teaching activities. At the present stage, the teaching mode is mainly embodied in the teacher-directed mode. In the development of football teaching activities, teachers are dominated in teaching, and students only play a supporting role in the learning activities. Teachers cannot pay attention to the need of students, and the development of teaching activities is not sufficiently targeted.

\section{In the aspect of faculty strength}

For the football teaching activities of colleges and universities, the professional quality level of football teachers has a very direct impact on the effectiveness of football teaching activities. At the present stage, the overall quality of college football teacher team needs to be further improved, and the number of football teachers is difficult to meet the growing demand for football teaching. Some football teachers have not been trained in relevant football professions and thus participate in teaching activities as amateurs. The overall teaching team lacks sufficient scientific research capabilities, and it is difficult to give constructive advice and guidance on how to better improve the quality and effectiveness of football teaching activities. At the same time, some colleges and universities lack sufficient attention to football professional teachers, and cannot provide them with a good environment for growth and training development. The development and construction of the overall teaching team has encountered many limitations and bottlenecks, which has led to the emergence of a series of problems in football teaching nowadays.

\section{In the aspect of teaching concept}

At the current stage of football teaching activities, the relevant concepts have not yet emerged from previous difficulties. Many teaching activities have not been carried out for long-term planning, and some football teachers believe that the football teaching activities in colleges and universities only need to make students master some basic skills of football and achieve the standard of academic requirement. However, they neither integrate football teaching with lifelong sports concepts well nor cultivate students' sports habits and consciousness, but 
only guide some specific short-term sports skills. Although students can maintain sufficient amount of exercise during the academic year, they seldom develop a sense of active exercise after graduation. Therefore, it is difficult to effectively implement the concept of "people-oriented" in the whole teaching process.

\section{ANALYSis OF FoOtBALl TEACHING IN SPORT UNIVERSITIES UNDER THE BACKGROUND OF INTERNET}

From the aspect of educational communication, network teaching has its advantages and limitations. Therefore, it is necessary to give full play to the advantages of network teaching and optimize traditional football teaching modes and methods. It requires teachers to study which courses in football teaching are more in line with the law of students' cognitive development and can effectively promote the growth of students. The teaching mode under the background of the Internet is based on the constructivism theory and aims to promote the development of students, which requires students to explore independently through the network, cooperate and communicate to complete the construction of knowledge under the guidance of questions or tasks. This mode is more acceptable to contemporary college students. From the perspective of students, the teaching mode under the background of the Internet is more suitable for the teaching of football theory classes than the traditional teaching mode.

\section{The CONStRuction OF FoOtBall TeACHing Mode in SPORT UNIVERSITY UNDER THE BACKGROUND OF THE INTERNET - VIRTUAL SITUATIONAL TEACHING MODE}

\section{A. Background conditions}

First, the main idea. The virtual situational teaching mode uses advanced network information technology to create virtual context as the problem background and makes use of an open task or a series of task strings which carry the teaching content to make students explore and learn independently, ask questions and analyze problems independently or corporately, solve problems, and finally achieve learning goals in the process of completing tasks. As a result, they can improve their self-learning ability and problem-solving ability, and cultivate their innovative thinking. It has three features. The first feature is "scenario center", which means the virtual situation is a "platform" for learners to solve problems. The second feature is "task-driven", which means the process of learners completing tasks is the process of constructing knowledge, and each task carries the teaching content and guides students to complete the teaching goal. The third feature is "student subject", which means each student is the subject of learning activities. In addition, the theoretical basis, also called constructive learning theory. Constructive learning theory advocates to regard students as the main body, and teachers only play the role of instructors, organizers, and supporters. Teachers should use the learning environment elements such as situation, collaboration and conversation to fully develop the initiative, enthusiasm, and innovation of learners, and ultimately achieve the purpose of making learners effectively achieve the construction of their current knowledge. Finally, the functional goal. The design of the virtual situation stimulates students' interest in learning, guides students to use their hands and brains and make use of their creative thinking to acquire knowledge, so as to improve students' ability to discover problems, analyze problems and solve problems, and cultivate students' active attitude and methods of inquiry. A conceptual framework of virtual situational teaching mode is shown in Fig. 1.

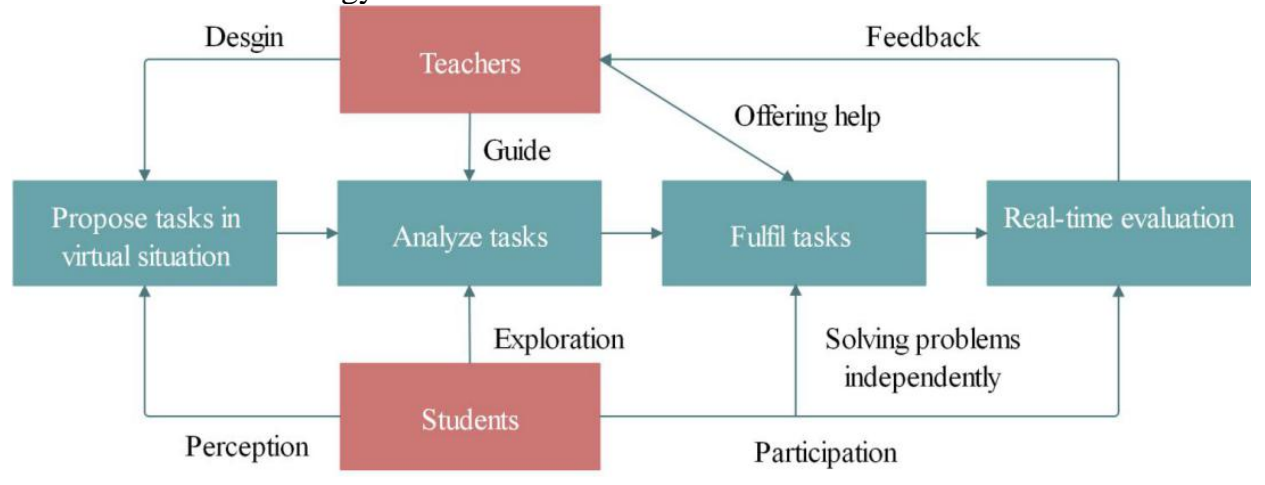

Fig.1. A conceptual framework of virtual situational teaching mode

\section{B. Experimental conditions}

The experimental conditions of the virtual situational teaching mode include physical conditions and non-physical conditions. The physical conditions are network courseware and computer classrooms with campus network. In the non-physical condition, teachers play the role of providers of learning resources as well as organizers and leaders of teaching. Students are the main body of the learning process, the explorer and the discoverer.

\section{Teaching practice}

According to the teaching practice, the main steps of the "virtual situational" teaching mode is roughly divided into four steps: first, creating a virtual situation, proposing tasks, and cultivating students' ability to discover problems. The situation is the basis of this teaching mode. Using network information technology can create virtual scenes that students like to see, so as to achieve a qualitative leap from traditional "static learning" to modern "dynamic learning". Therefore, the senses of students can be stimulated, and thus they can improve their learning efficiency. The task is the core of this teaching mode, 
and "task proposal" is the key to a lesson. Therefore, teachers should carefully design tasks according to students' cognitive level and their own experience as well as the relevant requirements of the outline and the curriculum, so that the task can not only carry the teaching content reasonably, but also help students develop. Second, in the process of analyzing the task, teachers should develop the thought of students. First of all, teachers should choose the appropriate teaching method according to the difficulty level of the task and whether it is established in the student's "proximal development zone" after the task is proposed. If the task is relatively simple, teachers can let students complete the task independently; if the task has certain difficulty, teachers can organize students to discuss with each other. Through the communication between teachers and students, teachers should guide students to clarify their thoughts step by step, find the connection between new and old knowledge, build knowledge construction for students, and complete knowledge transmits platform. In addition, teachers should organize students to design a plan to complete the task and develop the corresponding implementation steps. Finally, in the process of analyzing tasks, students will encounter various difficulties and problems. At this time, the role of teachers is not a wise man to answer questions, but a guide to lead the direction. Teachers should not provide students with answers but should provide ways to solve problems, such as retrieving relevant information, seeking help from classmates, and so on. The purpose of the above practice is to enable students with weak foundations to enter the study faster without polarization, and at the same time pay attention to the learning and mastery of students' learning methods, so as to promote the development of thinking. Third, in the process of completing the task, teachers should improve the students' ability to solve problems. Through the analysis of tasks and the setting of the program, students can enter the learning situation and clarify the learning objectives. Next, when students practice to complete the task, teachers should find out the problems that students have when completing the task as observers, especially the common problems. Teachers should also encourage students to think boldly and explore actively, provide necessary support for students as facilitators, and finally guide students to summarize and reflect in a timely manner as organizers to improve their thinking ability. Forth, in real-time evaluation, teachers should timely understand the learning situation of students and adjust teaching strategies accordingly. Computers will give corresponding evaluation, ranking, or score according to the student's completion, and students can take the learning evaluation as a screenshot to send to teachers' e-mail address. They can also record the entire process of completing the task and upload the video through the corresponding software. Teacher will evaluate students' situation according to the rating of computers and video, and adjust the teaching tasks of the next lesson according to students' situation.

\section{Evaluation method}

It evaluates from the aspects of cognition, emotion and energy, and combines formative evaluation and real-time evaluation.

\section{E. Applicable course type}

The virtual situational teaching mode is more applicable for tactical explanation teaching in football teaching.

\section{F. Case design}

\section{Learning objectives}

In the network-based learning environment, teachers impart the knowledge of "football wing attack", make students master important knowledge about the wing attack, guide students to understand the tactical characteristics of the wing attack through the heuristic education, and train students to take initiative for moral education.

\section{Analysis of academic situation}

Analysis of students' situation: The subject of this lesson is students who will be likely to engage in physical education and training work in the future. Therefore, in the classroom teaching, it is necessary to make students clarify the teaching method of "football wing attack" instead of just teaching technique and skills. In the process of teaching, teachers should infiltrate the spirit of teamwork and diligence to students. Analysis of learning attitude: Since these students need to take football as their main basis for employment in the future, they have strong motivation to learn and are more likely to have positive attitudes. Analysis of students' ability: Through previous courses of the football theory course, students have known some basic tactics. However, their abilities of independent learning and cooperative learning are weak, and they lack the spirit of mutual assistance, exploration and innovation. Analysis of information literacy: Through the undergraduate computer application courses, students have mastered the basic operational skills of computers, and can use some text and graphics processing software to communicate on the forum and use browsers to browse the web. A few students even have a high level of computer application. All students in the class can play computer games under the guidance of the game description.

\section{Analysis of teaching content}

"Football wing attack" is an important part of the football game, and it is also an important theoretical teaching content of the main part of the football education improvement course. The Syllabus Material of Football Improvement aims to enable students to understand the basic theoretical knowledge of football and master the basic skills of football. This course has a total of 48 lessons. At the same time, this lesson also chooses psychological development as an auxiliary textbook, which enables students to enhance their' friendship, mutual trust, solidarity and mutual assistance, so as to develop interpersonal relationships, realize the importance of integrating into the team, improve their mental health level, and enhance their ability of adapting the society.

\section{Selection of teaching information technology}

First, selection of teaching and learning environment: classrooms based on the local area network.

Second, learning software: [FIFA] game software and embedded player.

Third, teaching control tool: multimedia classroom control system.

Forth, network courseware development software: Microsoft Fronepage2003 and so on. 


\begin{tabular}{|c|c|c|c|}
\hline \multicolumn{4}{|l|}{ Teaching process } \\
\hline Teaching session & Teaching activities & Student activities & Design idea \\
\hline $\begin{array}{l}30 \text { minutes of } \\
\text { theoretical } \\
\text { knowledge } \\
\text { explain. }\end{array}$ & $\begin{array}{l}\text { Explain the "football wing } \\
\text { attack" tactic with PPT and } \\
\text { video. Necessary conditions } \\
\text { and precautions for using this } \\
\text { tactic. }\end{array}$ & $\begin{array}{l}\text { Understand the tactical } \\
\text { points and watch the } \\
\text { video of "football wing } \\
\text { attack" tactic selected by } \\
\text { teachers at home and } \\
\text { abroad. }\end{array}$ & $\begin{array}{l}\text { Tactical research is one of the focuses of this chapter. The author } \\
\text { believes that in order to enable students to better understand and } \\
\text { master the content of this part, it is not enough to only have a } \\
\text { statement of words, but should have an animation to enhance its } \\
\text { impression. Therefore, the author downloaded a lot of flash } \\
\text { animations from the network to enrich the courseware of the } \\
\text { online class. The following is a screenshot of some videos and } \\
\text { some courseware. }\end{array}$ \\
\hline \multirow[t]{3}{*}{$\begin{array}{l}60 \text { minutes of } \\
\text { applied tactical } \\
\text { practice. }\end{array}$} & $\begin{array}{l}\text { Arrange learning tasks, use } \\
\text { the wing attack tactics } \\
\text { learned to form a team to } \\
\text { play online games. }\end{array}$ & $\begin{array}{l}\text { Students learn the } \\
\text { operation method for } 5 \\
\text { minutes. }\end{array}$ & Let students adapt to learning in the online environment. \\
\hline & $\begin{array}{l}\text { Instruct students to conduct } \\
\text { tactical game matches. }\end{array}$ & $\begin{array}{l}\text { Use wing attack tactics } \\
\text { to conduct online match }\end{array}$ & $\begin{array}{l}\text { In tactical practice, students enter the Football Manager game, } \\
\text { select the wing attack, and choose computer or classmates as an } \\
\text { opponent to play games. Students are required to record the whole } \\
\text { process, so that teachers can evaluate in real time based on } \\
\text { student's completion: } 55 \text { minutes. }\end{array}$ \\
\hline & $\begin{array}{l}\text { Organize students to submit } \\
\text { game results }\end{array}$ & $\begin{array}{l}\text { Take a screenshot of the } \\
\text { game video and final } \\
\text { score, mark the class } \\
\text { name, and upload it to } \\
\text { the teacher's mailbox. }\end{array}$ & Easy for teacher evaluation \\
\hline \multicolumn{4}{|c|}{$\begin{array}{l}\text { Estimated problems } \\
\text { In one lesson, different students have different cognitive structure, quality of thinking, and ability level. This course mainly allows students to } \\
\text { understand the tactical characteristics of the wing attack and master the basic methods, and students are required differently based on their } \\
\text { characteristics. The Excellent students can be selected, and at the end of the part, they can have a video demonstration to fully show their talents, so as } \\
\text { to achieve the purpose of teaching. }\end{array}$} \\
\hline
\end{tabular}

\section{SUMMARY}

This work analyzed the shortcomings of traditional football teaching in colleges and universities, combined modern educational technology theory with football teaching theory and modern learning theory according to the characteristics of the Internet, and constructed a "virtual situational" network sports teaching mode under the background of the Internet. It aimed to promote the reform of football teaching mode and teaching methods in sport universities and promote the development of teaching mode in colleges and universities based on the Internet.

\section{REFERENCES}

[1] Hu, X., \& Zhou, M.. The three-dimensional teaching mode of ERP course in colleges and universities. International Conference on E-business \& E-government. IEEE, 2011.
[2] Gullatt, \& David, E.. Enhancing student learning through arts integration: implications for the profession. The High School Journal, 91(4), 12-25. 2008.

[3] Sheng-Yu, S.. On the realization strategy of scientific teaching of football training in colleges and universities. Journal of Jiamusi Vocational Institute, 2008.

[4] Zhipeng, H., Li, L., Xiaoyi, X., Haibing, D., Gaochen, S., \& University, M. M.. Exploration and application of new mode of teaching practice in biochemistry teaching. Guangdong Chemical Industry, 2014.

[5] Mingde, C., Zhentian, L., Yubin, L., \& Amp, S. M.. Language code transfer-new mode of bilingual teaching. Educational Research, 2017.

[6] Harris, A., \& Spence, M.. ।"disturbing the complacency of religionl"? the evangelical crusades of dr billy graham and father Patrick Peyton in britain, 1951-54. Twentieth Century British History, 18(4), 481-513. 2017.

[7] Bin, Z., Yufei, Y., \& Hongan, D.. Application of basketball tactics in five-player football teaching. Journal of Physical Education, 2010.

[8] Yu, A.. Study on University Football Teaching Based on Multimedia Technology. Informatics and Management Science V. Springer London, 2013

[9] Wu, J.. Experimental research on application of mutual-aid teaching method in technique teaching of university's football elective course, 2010. 